\title{
Fundusze strukturalne dla bibliotek w okresie programowania 2007-2013
}

StreszCzenie. Polska $w$ ramach funduszy strukturalnych otrzyma w okresie programowania 2007-2013 około 67,3 mld euro. Jest to największa pomoc przyznana dotychczas państwu członkowskiemu w ramach Polityki Spójności Unii Europejskiej. Przed bibliotekami - zarówno naukowymi, jak również publicznymi czy nawet szkolnymi pojawiła się więc kolejna szansa na dofinansowanie działalności. W artykule przedstawione są możliwości skorzystania przez te instytucje z funduszy strukturalnych w latach 2007-2013 w ramach Programu Operacyjnego Infrastruktura i Środowisko, Programu Operacyjnego Rozwój Polski Wschodniej, Wielkopolskiego Regionalnego Programu Operacyjnego oraz Programu Operacyjnego Kapitał Ludzki.

SŁOWA KLUCzowe: biblioteka, Unia Europejska, programy operacyjne, fundusze strukturalne, środki pozabudżetowe, fundusze bibliotek

W ramach funduszy strukturalnych Polska otrzyma w okresie programowania $^{1}$ 2007-2013 około 67,3 mld euro². Jest to największa (dotychczas) pomoc przyznana państwu członkowskiemu w ramach Polityki Spójności ${ }^{3}$ Unii Europejskiej.

W latach 2007-2013 funkcjonują w Polsce dwa fundusze strukturalne ${ }^{4}$ : Europejski Fundusz Rozwoju Regionalnego(EFRR) oraz Europejski Fun-

${ }^{1}$ Okres programowania - wieloletni okres planowania budżetu Unii Europejskiej, okres obowiązywania dokumentów programowych stanowiących podstawę do ubiegania się o wsparcie ze strony Komisji Europejskiej.

${ }^{2}$ Zob. Kompendium wiedzy o Unii Europejskiej, red. E. Małuszyńska, B. Gruchman, Warszawa 2007, s. 316.

${ }^{3}$ Polityka spójności - wspieranie wszechstronnego i harmonijnego rozwoju w UE, a zwłaszcza zmniejszanie różnic w poziomie rozwoju gospodarczego.

${ }^{4}$ Fundusze strukturalne - fundusze tworzone w budżecie Wspólnoty Europejskiej, umożliwiające pomoc w restrukturyzacji i modernizacji gospodarki krajów członkowskich przez interwencję w kluczowych sektorach i regionach - poprawa struktury. 
dusz Społeczny (EFS). W ich ramach uruchomionych zostanie kilkanaście programów operacyjnych: Program Operacyjny Infrastruktura i Środowisko, Program Operacyjny Innowacyjna Gospodarka, Program Operacyjny Kapitał Ludzki, Program Operacyjny Rozwój Polski Wschodniej, Program Operacyjny Europejskiej Współpracy Terytorialnej, Program Operacyjny Pomoc Techniczna oraz 16 regionalnych programów operacyjnych.

Przed bibliotekami - zarówno naukowymi, jak również publicznymi czy nawet szkolnymi - pojawiła się więc kolejna perspektywa na dofinansowanie działalności. W niniejszym artykule przedstawione zostaną najważniejsze szanse skorzystania przez te instytucje z funduszy strukturalnych w latach 2007-2013. W ramach prezentacji regionalnego programu operacyjnego przedstawiono możliwości, jakie daje Wielkopolski Regionalny Program Operacyjny. Każde z pozostałych 15 województw stawia jednak podobne szanse przed bibliotekami.

\section{Program Operacyjny Infrastruktura i Środowisko}

Program Operacyjny Infrastruktura i Środowisko zapewnia możliwość ubiegania się o dofinansowanie m.in. w dziedzinie gospodarki wodno-ściekowej, gospodarki odpadami i ochrony powierzchni ziemi, infrastruktury drogowej, bezpieczeństwa energetycznego i ochrony przyrody, ale jednym z priorytetów programu są również kultura i dziedzictwo kulturowe oraz infrastruktura szkolnictwa wyższego. Instytucją Zarządzającą $^{5}$ tym programem jest Ministerstwo Rozwoju Regionalnego.

\subsection{Priorytet XI - Działanie 11.1 PO IŚ - Ochrona i zachowanie dziedzictwa kulturowego o znaczeniu ponadregionalnym}

Funduszem finansującym to działanie jest Europejski Fundusz Rozwoju Regionalnego, Instytucją Pośredniczącą ${ }^{6}$ - Ministerstwo Kultury i Dziedzictwa Narodowego. Wszelkie informacje można uzyskać na stronie internetowej www.mkidn.gov.pl. Celem Działania są m.in. ochrona, zachowanie, efektywne wykorzystanie dziedzictwa kulturowego o znaczeniu ponadregionalnym, poprawa stanu zabytków oraz wzrost znaczenia

${ }^{5}$ Instytucja Zarządzająca - właściwy minister albo inny organ administracji publicznej odpowiedzialny za przygotowanie i nadzorowanie realizacji programu operacyjnego.

${ }^{6}$ Instytucja Pośrednicząca - instytucja, do której Instytucja Zarządzająca deleguje część funkcji związanych z zarządzaniem, kontrolą i monitorowaniem programu operacyjnego, odnosząca się do priorytetu operacyjnego, działania albo projektu. 
kultury w kreowaniu miejsc pracy. Przykładowe projekty, które wskazuje Szczegółowy Opis Priorytetów Programu Operacyjnego Infrastruktura i Środowisko ${ }^{7}$, to konserwacja zabytkowych muzealiów, starodruków, księgozbiorów oraz archiwaliów i zbiorów filmowych o szczególnej wartości historycznej, jak również rozwój zasobów cyfrowych w dziedzinie kultury, w tym digitalizacja zabytkowych zasobów bibliotecznych i muzealnych oraz archiwaliów i zbiorów filmowych o szczególnej wartości historycznej. Ponadto instytucje kultury, w tym biblioteki, mogą skorzystać ze środków przeznaczonych na rewitalizację, rewaloryzację, konserwację, renowację, zachowanie, adaptację na cele kulturalne obiektów wpisanych do rejestru zabytków; zabezpieczenie zabytków przed kradzieżą i zniszczeniem oraz tworzenie wirtualnych instytucji kultury. Ten ostatni przypadek dotyczy wykorzystania zbiorów zabytkowych lub o szczególnej wartości historycznej. Beneficjentami pomocy w ramach Priorytetu XI - Działanie 11.1 PO IŚ są m.in. państwowe i samorządowe instytucje kultury, jednostki samorządu terytorialnego oraz publiczne uczelnie wyższe. Alokacja finansowa na Działanie wynosi 118,85 mln euro. Projekty realizowane w ramach tego Działania nie są jednak dostępne dla małych bibliotek, gdyż minimalna wartość projektu to 4 mln złotych, a w przypadku niektórych projektów nawet 20 mln złotych.

\subsection{Priorytet XI - Działanie 11.2 PO IŚ - Rozwój oraz poprawa stanu infrastruktury kultury o znaczeniu ponadregionalnym}

Funduszem finansującym to Działanie jest - podobnie jak w przypadku Działania 11.1 PO IŚ - Europejski Fundusz Rozwoju Regionalnego, a Instytucją Pośredniczącą - Ministerstwo Kultury i Dziedzictwa Narodowego. Celem Działania jest zwiększenie dostępu do kultury, poprawa jakości oferty kulturalnej oraz wzrost atrakcyjności kraju dla mieszkańców, inwestorów i turystów. Również biblioteki mają możliwość pozyskiwania środków w ramach tego Działania, gdyż zakładane w Szczegółowym Opisie Priorytetów przykładowe projekty to budowa, rozbudowa, remont i przebudowa instytucji kultury oraz zakup i remont trwałego wyposażenia do prowadzenia działalności kulturalnej. Beneficjentami wsparcia mogą być m.in. instytucje kultury oraz jednostki samorządu terytorialnego. Cała alokacja finansowa na lata 2007-2013 wynosi 357,59 mln euro, minimalna wartość projektu to 4 mln złotych, a w niektórych przypadkach nawet $20 \mathrm{mln}$ złotych.

${ }^{7}$ Por. http://www.pois.gov.pl/Dokumenty/Lists/Dokumenty\%20programowe/Attachments/93/SzOP_POIiS_v_3_1_130509.pdf [dostęp: 8.06.2009]. 


\subsection{Priorytet XIII - Działanie 13.1 PO IŚ - Infrastruktura szkolnictwa wyższego}

Kolejnym działaniem dostępnym wyłącznie dla bibliotek akademickich jest Działanie 13.1 Programu Operacyjnego Infrastruktura i Środowisko. Funduszem finansującym to Działanie jest Europejski Fundusz Rozwoju Regionalnego, Instytucją Pośredniczącą - Ministerstwo Nauki i Szkolnictwa Wyższego. Informacje o organizowanych konkursach można znaleźć na stronie internetowej www.mnisw.gov.pl. Celem Działania jest rozwój nowoczesnych ośrodków akademickich kształcących przede wszystkim specjalistów w zakresie najnowszych technologii (architektura, urbanistyka, automatyka, robotyka, biologia, biotechnologia i inne zawarte w Szczegółowym Opisie Priorytetów Programu Operacyjnego Infrastruktura i Środowisko). W ramach Działania zakłada się m.in. budowę, rozbudowę lub przebudowę istniejących obiektów infrastruktury szkół wyższych wraz z wyposażeniem w aparaturę dydaktyczno-badawczą. Elementem dopełniającym etap kształcenia jest zapewnienie odpowiedniego zaplecza związanego z obsługą studenta, dlatego też w zakresie ograniczonym do $25 \%$ kosztów kwalifikowalnych projektu ${ }^{8}$ wsparcie może zostać przeznaczone na rzecz tzw. infrastruktury towarzyszącej wykorzystywanej przez studentów, np. obiektów socjalnych, obiektów sportowo-rekreacyjnych i bibliotek. Alokacja finansowa na Działanie wynosi 588,24 mln euro, zaś minimalna wartość projektu $20 \mathrm{mln} z ł$.

\section{Wielkopolski Regionalny Program Operacyjny}

Wielkopolski Regionalny Program Operacyjny ze względu na typ realizowanych projektów wydaje się bardziej dostępny dla mniejszych bibliotek publicznych niż Program Operacyjny Infrastruktura i Środowisko. Instytucją Zarządzającą tym Programem jest Zarząd Województwa Wielkopolskiego. Wszystkie informacje o bieżących konkursach znaleźć można na stronie internetowej www.wrpo.wielkopolskie.pl.

${ }^{8}$ Koszty kwalifikowalne - koszty niezbędne do realizacji projektu współfinansowanego ze środków UE, możliwe do weryfikacji (udokumentowane), rzetelne, wyliczone w sposób proporcjonalny do okresu realizacji projektu. 


\subsection{Priorytet II - Działanie 2.7 WRPO - Infrastruktura społeczeństwa informacyjnego}

Funduszem finansującym to Działanie jest Europejski Fundusz Rozwoju Regionalnego. Celem działania jest m.in. zwiększenie dostępu do usług świadczonych drogą elektroniczna, np. przez rozbudowę sieci Internetu szerokopasmowego, oraz rozwój gospodarczy i społeczny województwa przez poprawę warunków dostępu do Internetu, rozwój komunikacji i publicznych e-usług, takich jak np. e-administracja, e-edukacja, e-zdrowie. Przykładowe rodzaje projektów wskazane w Uszczegółowieniu Wielkopolskiego Regionalnego Programu Operacyjnego ${ }^{9}$ to projekty infrastrukturalne związane z przygotowaniem instytucji publicznych, np. lokalnej administracji samorządowej, oświaty, edukacji do elektronicznego obiegu dokumentów, rozwoju elektronicznych usług dla ludności oraz elektronicznej archiwizacji dokumentów. Warto podkreślić, że w tym ostatnim przypadku digitalizacja nie stanowi kosztu kwalifikowalnego. W ramach Programu można ubiegać się o środki na tworzenie publicznych punktów dostępu do Internetu, hot-spotów oraz infokiosków w obiektach publicznie dostępnych, np. w bibliotekach publicznych, domach kultury, szkołach, szkołach wyższych czy świetlicach gminnych. W przypadku konieczności digitalizacji zbiorów można ubiegać się o środki na stworzenie, udostępnienie, wdrożenie systemu, zakup oprogramowania dotyczącego digitalizacji zbiorów bibliotecznych, archiwalnych, filmowych i muzealnych (podobnie jak wyżej koszty digitalizacji nie stanowią kosztu kwalifikowalnego). Ciekawą możliwością zaprezentowania zbiorów, w tym zbiorów zabytkowych, jest stworzenie wirtualnego muzeum lub biblioteki cyfrowej, jak również utworzenie galerii, fonotek lub filmotek. W ramach Działania 2.7 można skorzystać z cross-financingu przez szkolenia pracowników obsługujących zakupiony sprzęt. Cross-financing to elastyczny sposób finansowania projektów, polegający na dofinansowaniu $\mathrm{w}$ ramach projektu $\mathrm{z}$ udziałem środków z EFRR komplementarnych działań wchodzących w zakres EFS oraz dofinansowaniu w ramach projektu z udziałem środków z EFS komplementarnych działań wchodzących w zakres EFRR ${ }^{10}$. Typem beneficjentów mogących ubiegać się o dofinansowanie są m.in. szkoły wyższe, instytucje kultury, jak również osoby prawne i fizyczne będące organami prowadzącymi szkoły i placówki oświatowe. Alokacja finansowa na Działanie wynosi 194,05 mln euro.

${ }^{9}$ Por. http://www.wrpo.wielkopolskie.pl/index.php?option=com_content\&view= article\&id=488\&Itemid=110 [dostęp: 8.06.2009].

${ }^{10}$ Zob. http://www.funduszeeuropejskie.gov.pl/Slownik/Strony/Cross-financing.aspx [dostęp: 8.06.2009]. 


\subsection{Priorytet V - Działanie 5.1 WRPO - Infrastruktura szkolnictwa wyższego}

Funduszem finansującym to Działanie jest Europejski Fundusz Rozwoju Regionalnego. Celem Działania jest m.in. zwiększenie dostępności i poprawa jakości kształcenia na poziomie wyższym, tworzenie warunków do wzrostu zatrudnienia oraz zapewnienie wzrostu konkurencyjności regionu. Wśród głównych celów wymienić można również budowę, rozbudowę, przebudowę, wyposażenie obiektów infrastruktury społeczno-edukacyjnej, służącej do prowadzenia działalności dydaktycznej na poziomie wyższym. Przykładowe projekty, które wskazuje Uszczegółowienie Wielkopolskiego Regionalnego Programu Operacyjnego, to budowa nowych, rozbudowa lub przebudowa istniejących laboratoriów dydaktycznych, pracowni komputerowych, bibliotek, jak również wyposażenie placówek dydaktycznych $\mathrm{w}$ nowoczesny sprzęt i pomoce optymalizujące proces kształcenia. Co istotne dla bibliotek, kosztem niekwalifikowalnym w ramach tego działania jest koszt zakupu książek. Potencjalni beneficjenci to m.in. szkoły wyższe, osoby prawne i fizyczne będące organami prowadzącymi szkoły i placówki oświatowe oraz jednostki naukowe prowadzące działalność edukacyjną. Alokacja finansowa na Działanie wynosi 67,464 mln euro.

\subsection{Priorytet V - Działanie 5.2 WRPO - Rozwój infrastruktury edukacyjnej, w tym kształcenia ustawicznego}

Funduszem finansującym to Działanie jest Europejski Fundusz Rozwoju Regionalnego. Celem Działania jest m.in. poprawa warunków kształcenia, unowocześnienie i wzbogacenie bazy regionalnych placówek oświatowych na poziomie podstawowym, gimnazjalnym i ponadgimnazjalnym, a także kształcenia ustawicznego oraz wyrównanie szans w dostępie do edukacji podstawowej i średniej uczniów z terenów wiejskich. Beneficjenci mogą skorzystać z dofinansowania na budowę nowych, rozbudowę i przebudowę istniejących bibliotek przyszkolnych. Podobnie jak w Działaniu 5.1 WRPO - Infrastruktura szkolnictwa wyższego - kosztem kwalifikowalnym nie jest koszt zakupu książek. Ponadto istnieje możliwość wyposażenia placówek edukacyjnych w nowoczesny sprzęt - poza komputerowym w przypadku gdy projekt nie obejmuje budowy lub rozbudowy obiektu dydaktycznego - i pomoce optymalizujące proces kształcenia, co również może dotyczyć doposażenia np. bibliotecznych czytelni. Typ beneficjentów wskazany w dokumentach programowych to m.in. jednostki samorządu terytorialnego, osoby prawne i fizyczne będące organami 
prowadzącymi szkoły i placówki oświatowe oraz jednostki naukowe. Alokacja finansowa na Działanie wynosi 19,58 mln euro.

\subsection{Priorytet VI - Działanie 6.2 WRPO - Rozwój kultury i zachowanie dziedzictwa narodowego}

Funduszem finansującym to Działanie jest Europejski Fundusz Rozwoju Regionalnego. Celem Działania jest m.in. poprawa dostępności mieszkańców Wielkopolski do dóbr i usług kultury, jak również ochrona i zachowanie dziedzictwa kulturowego. Beneficjenci mogą skorzystać ze środków na konserwację zabytkowych muzealiów, archiwaliów, starodruków, księgozbiorów oraz innych zabytków ruchomych, zabezpieczenie zabytków przed kradzieżą i zniszczeniem, a także budowę, rozbudowę i przebudowę publicznej infrastruktury kultury. Z uwagi na fakt, że biblioteki pełnią funkcję instytucji kultury, mogą one składać wnioski i ubiegać się o dofinansowanie kampanii promocyjnych w kraju i za granica, których celem jest promocja kultury regionu. Typ beneficjentów to m.in. instytucje kultury (samorządowe, państwowe), jednostki samorządu terytorialnego oraz instytucje non profit (w rozumieniu ustawy o organizowaniu i prowadzeniu działalności kulturalnej). Alokacja finansowa na Działanie wynosi 37,98 mln euro.

\section{Program Operacyjny Rozwój Polski Wschodniej}

Program Operacyjny Rozwój Polski Wschodniej skierowany jest do mieszkańców województw: lubelskiego, podkarpackiego, świętokrzyskiego, podlaskiego i warmińsko-mazurskiego. Instytucją Zarządzającą jest Ministerstwo Rozwoju Regionalnego. Działanie 1.1 PO RPW - Infrastruktura uczelni - zakłada możliwość ubiegania się o dofinansowanie projektów związanych z budową i innymi robotami budowlanymi oraz wyposażeniem w sprzęt naukowo-badawczy obiektów dydaktycznych, w tym laboratoriów, pracowni komputerowych oraz bibliotek i skierowany jest m.in. do uczelni publicznych i niepublicznych działających na terenie wymienionych województw. Alokacja finansowa na to Działanie wynosi 396867611,94 euro $^{11}$.

${ }^{11}$ Zob.http://www.polskawschodnia.gov.pl/Dokumenty/Lists/Dokumenty\%20programowe/Attachments/89/Szczegolec_27_04_09 $\% 20$ wersja_jednolita.pdf [dostęp: 25.07.2009]. 


\section{Program Operacyjny Kapitał Ludzki}

Dotychczas opisane działania współfinansowane były z Europejskiego Funduszu Rozwoju Regionalnego. Biblioteki jednak nie tylko muszą rozwijać się pod względem infrastrukturalnym, ale powinny też dążyć do ciągłego podnoszenia wiedzy i umiejętności swoich pracowników, jak również pełnić funkcję edukacyjną i funkcję kulturalną. Cele te mogą zostać osiągnięte przez skorzystanie ze środków w ramach Europejskiego Funduszu Społecznego. Programem operacyjnym finansowanym ze środków tego funduszu strukturalnego jest w perspektywie okresu programowania 2007-2013 Program Operacyjny Kapitał Ludzki.

Celem działań, które są finansowane ze środków Europejskiego Funduszu Społecznego, jest m.in. przeciwdziałanie bezrobociu, rozwój zasobów ludzkich, wspieranie edukacji i wyrównywanie szans na rynku pracy. Za pomocą Programu Operacyjnego Kapitał Ludzki realizuje się jeden z głównych celów Narodowej Strategii Spójności, jakim jest tworzenie warunków dla wzrostu konkurencyjności gospodarki polskiej opartej na wiedzy i przedsiębiorczości, zapewniającej wzrost zatrudnienia i wzrost poziomu spójności społecznej, gospodarczej i przestrzennej. Program ukierunkowany jest na umożliwienie pełnego wykorzystania potencjału zasobów ludzkich przez wzrost zatrudnienia i potencjału adaptacyjnego przedsiębiorstw i ich pracowników, podniesienie poziomu wykształcenia społeczeństwa, zmniejszenie obszarów wykluczenia społecznego oraz wsparcie budowy struktur administracyjnych państwa. W ramach Programu Operacyjnego Kapitał Ludzki objęto pomocą następujące obszary: zatrudnienie, edukacja, integracja społeczna, rozwój potencjału adaptacyjnego pracowników i przedsiębiorstw, a także zagadnienia związane z rozwojem zasobów ludzkich na terenach wiejskich, z budową sprawnej i partnerskiej administracji publicznej wszystkich szczebli oraz z promocją zdrowia ${ }^{12}$. Głównymi czynnikami współczesnego, zrównoważonego rozwoju są: poziom zatrudnienia, stopień integracji społecznej oraz budowa społeczeństwa i gospodarki opartych na wiedzy. Wszystkie te czynniki uwzględnione będą w działaniach realizowanych w ramach PO KL ${ }^{13}$. Instytucją Zarządzającą tym programem jest Ministerstwo Rozwoju Regionalnego, a Instytucją Pośredniczącą w Wielkopolsce w ramach Priorytetów VI-IX PO KL - Wojewódzki Urząd Pracy w Poznaniu (www.wup. poznan.pl).

${ }^{12}$ Por. Program Operacyjny Kapitał Ludzki, Biuletyn informacyjny nr 4/2008, Wojewódzki Urząd Pracy w Poznaniu.

${ }^{13}$ Por. W. Miś, Kapitał ludzki w gospodarce rynkowej, Warszawa 2007, s. 101. 


\subsection{Priorytet VIII - Poddziałanie 8.1.1 PO KL - Wspieranie rozwoju kwalifikacji zawodowych i doradztwo dla przedsiębiorstw}

Celem Działania jest stymulowanie podnoszenia i aktualizacji kompetencji zawodowych przez osoby pracujące, m.in. przez udział w szkoleniach (zgodnie ze Szczegółowym Opisem Priorytetów Programu Operacyjnego Kapitał Ludzki 2007-2013 to szkolenia skierowane do dorosłych osób pracujących, które z własnej inicjatywy są zainteresowane nabyciem nowych, uzupełnianiem lub podwyższaniem kwalifikacji i umiejętności $\left.{ }^{14}\right)$. Uczestnicy powinni być zatrudnieni na podstawie umowy o pracę lub umowy cywilnoprawnej. W ten sposób również pracownicy wszystkich typów bibliotek mają możliwość wzięcia udziału m.in. w bezpłatnych szkoleniach językowych, komputerowych lub warsztatach dotyczących umiejętności interpersonalnych. Informacje o nich znaleźć można m.in. na stronie www.inwestycjawkadry.pl, jak również w mediach lokalnych. Ogłoszenia prasowe, plakaty lub ulotki o bezpłatnych szkoleniach są opatrzone logotypem Programu Operacyjnego Kapitał Ludzki oraz Unii Europejskiej. Alokacja finansowa na Działanie 8.1 wynosi 1270783 690,00 euro.

\subsection{Priorytet VII - Działanie 7.3 PO KL - Inicjatywy lokalne na rzecz aktywnej integracji oraz Priorytet IX - Działanie 9.5 PO KL - Oddolne inicjatywy lokalne na obszarach wiejskich}

Zgodnie ze Szczegółowym Opisem Priorytetów PO KL 2007-2013 obszary wiejskie są miejscem spiętrzenia wielu problemów rozwojowych, które na ogół są trudniejsze do rozwiązania niż na terenie miast. W znacznym zakresie dotyczy to edukacji, do której dostęp na obszarach wiejskich jest dużo gorszy niż w dużych aglomeracjach miejskich. Jednocześnie świadomość wielu mieszkańców obszarów wiejskich w zakresie wagi edukacji i wykształcenia dla życia zawodowego i społecznego jest niższa niż w przypadku mieszkańców miast. W rezultacie zjawiska te ogniskują się w negatywnych wskaźnikach edukacyjnych w odniesieniu do obszarów wiejskich, należą do nich m.in. niższy poziom wykształcenia mieszkańców obszarów wiejskich, niższy stopień upowszechnienia edukacji przedszkolnej, gorsze osiągnięcia edukacyjne uczniów pochodzących z obszarów wiejskich czy niższy stopień upowszechnienia kształcenia ustawicznego. Na tym tle jako znaczący problem należy postrzegać zbyt niski stopień aktywności mieszkańców wsi w zakresie samoorganizacji

14 Zob. http://www.mrr.gov.pl/Aktualnosci/Documents/Szop_nowelizacja_1_6_2009_ POKL.pdf [dostęp: 8.06.2009]. 
i podejmowania oddolnych inicjatyw na rzecz rozwiązywania problemów społeczności wiejskich w obszarze edukacji. W ramach Działania 7.3 PO KL realizowane są projekty przyczyniające się do integracji społecznej mieszkańców obszarów wiejskich oraz rozwoju usług społecznych na tych obszarach; wspomagające wsparcie inicjatyw lokalnych o charakterze informacyjnym, szkoleniowym i promocyjnym (np. w formie szkoleń, spotkań, seminariów, których celem jest przeciwdziałanie wykluczeniu społecznemu mieszkańców obszarów wiejskich) oraz zapewniające rozwój dialogu, partnerstwa publiczno-społecznego i współpracy na rzecz rozwoju zasobów ludzkich na poziomie lokalnym. W ramach Działania 9.5 PO KL realizowane są: wsparcie na rzecz mieszkańców obszarów wiejskich ukierunkowane na rozwój oferty edukacyjnej na obszarach wiejskich, wzmocnienie znaczenia instytucji oświatowych w środowiskach lokalnych oraz podniesienie poziomu wykształcenia mieszkańców obszarów wiejskich, a zwłaszcza umiejętności zawodowych przydatnych poza rolnictwem. Wszystkie powyższe instrumenty mają prowadzić do zmniejszenia zróżnicowań w obszarze edukacji pomiędzy obszarami wiejskimi a ośrodkami miejskimi. W Działaniu przewidziano formy wsparcia, przyczyniające się do poprawy sytuacji edukacyjnej wsi, które odpowiadają specyfice obszarów wiejskich i zgodnie z nią będą wykazywać wysoką skuteczność, tj. wsparcie na rzecz tworzenia i podejmowania aktywności przez lokalne inicjatywy i pakty na rzecz rozwiązywania problemów mieszkańców wsi w obszarze edukacji. W przypadku obu Działań wsparcie zostało skierowane do gmin wiejskich, miejsko-wiejskich oraz miast do 25 tys. mieszkańców. Zgodnie ze specyfiką obszarów wiejskich oraz potencjalnych ostatecznych odbiorców wsparcia działających na tych obszarach system wdrażania Priorytetów został skierowany do podmiotów o mniejszym potencjale organizacyjnym (które nie miałyby możliwości realizacji projektów w ramach pozostałych Działań Priorytetów VII lub IX) i obejmuje realizację małych projektów (do 50 tys. zł) skierowanych do niewielkich społeczności lokalnych i oddziałujących na rzecz ich aktywizacji. Możliwość skorzystania z tych "małych” projektów mają przede wszystkim biblioteki publiczne, które mogą na przykład zorganizować spotkania edukacyjne, warsztaty teatralne i filmowe, spotkania poetyckie, szkolenia, warsztaty i kursy dla mieszkańców obszaru ich działalności, jak również skorzystać z możliwości promocji regionu czy spotkań z autorami książek.

Przegląd programów operacyjnych miał na celu wskazanie możliwości ubiegania się o dofinansowanie ze środków Unii Europejskiej przez biblioteki. Należy jednak mieć na uwadze to, że wytyczne programowe 
podlegają ciągłym zmianom, dlatego - w przypadku złożenia wniosku o dofinansowanie projektu i jego pozytywnego rozpatrzenia - należy stale sprawdzać aktualne wersje dokumentów, najlepiej na oficjalnej stronie poświęconej funduszom europejskim w latach 2007-2013: www.funduszeeuropejskie.gov.pl.

Niektóre z polskich bibliotek wykorzystały już w poprzednim bądź obecnym okresie programowania szanse, jakie oferuje Unia Europejska. Wiąże się to oczywiście z dodatkową pracą (przygotowaniem, wdrożeniem i rozliczeniem projektu), daje jednak kolejne możliwości, by budować społeczeństwo oparte na wiedzy i rozwijać znaczenie oraz funkcje bibliotek.

\section{MARIA WOJCIŃSKA, DAMIAN WOJCIŃSKI}

\section{Structural funds for libraries in the agenda for 2007-2013}

Abstract. Within the framework of the structural funds Poland will receive approximately 67.3 billion euros between the years 2007-2013. It is the biggest offered financial support a member state has been assigned to within the Cohesion Policy of the European Union ever. Hence, libraries in Poland, both academic and public, or even school libraries, have been given another chance of co-financing their activity. The article presents the possibilities at hand of these institutions offered by the structural funds for 2007-2013 within the following priority projects: the Operational Programme Infrastructure and Environment, the Operational Programme Development of Eastern Poland, the Wielkopolska Regional Operational Programme and the Operational Programme Human Capital.

KEY wORDs: library, European Union, operational programmes, structural funds, nonbudgetary funds, library funds 